\title{
Avouía in Matthew: An Exegetical Analysis of its Meaning ${ }^{1}$
}

\author{
Masashi Sawamura \\ Hiroshima Jogakuin University, Japan
}

\begin{abstract}
àvouí $\alpha$ is an important keyword in the Gospel according to Matthew. A majority of scholars have claimed that $\dot{\alpha} v o \mu$ í $\alpha$ indicates the existence of an antinomian sub-group within the Matthean community, based on Matthew's harsh polemic against his opponents. Other scholars have asserted that $\alpha$ vouía does not connote any specific teaching or attitude against the law, for there is no evidence that Matthew had ever confronted a threat from an antinomian group. Each of these arguments has some legitimacy, so that here we find an exegetical difficulty concerning the target of $\dot{\alpha} v o \mu i^{\alpha} \alpha$ in Matthew. This study attempts to solve this apparent contradiction through exegetical analysis of the usage of $\alpha v o \mu$ í in Matthew to show that his use of this term deeply reflects the Matthean polemical strategy and the purpose of writing his Gospel.
\end{abstract}

In the discussion about the polemic in Matthew's Gospel, the term $\alpha$ vo $\mu$ í $\alpha$ has often been treated as the clue to identify the background of Matthew. However, it is not clear from the context itself to whom Matthew is attributing $\alpha v^{\prime} \mu \mu^{\prime} \alpha$, and attempts have been made to identify the subject of the term.

This study attempts to examine this term in Matthew to find consistency in its usage and further try to clarify the meaning of this term in the aim of identifying the intention of Matthew in the polemic.

This work was supported by KAKENHI (Grant-in-Aid for Scientific Research) (C) of the Japan Society for the Promotion of Science (subject \#17K02240).

William Loader, Boris Repschinski, Eric Wong (Eds.)

Matthew, Paul, and Others: Asian Perspectives on New Testament Themes

(C) 2019 innsbruck university press, ISBN 978-3-903187-66-5, DOI 10.15203/3187-66-5 


\section{Avouía in the Septuagint}

Avouía is found 243 times in 230 verses in the LXX and the majority of the uses can be found within Psalms ( 80 times in 77 verses). The second largest number of instances is 49 times in 45 verses in Ezekiel and the third is 24 times in 23 verses in Isaiah.

In the LXX, $\dot{\alpha} v o \mu i \alpha$ corresponds to 30 different Hebrew words. Within this variety, four Hebrew words are most frequently translated as $\alpha v o \mu i ́ \alpha$ :

- $\quad$ - עy - the most frequent and found 63 times throughout OT, including 24 times in Psalms, the most frequent occurrence.

- 25 times in Ezekiel along with only one instance in Jeremiah.

- $\quad 23$ times in Psalms along with once each in Job and Isaiah.

- $\quad$ עשָׁ- 19 times: nine in Isaiah, seven in Psalms and three in Job.

As this observation shows, $\dot{\alpha} v o \mu$ í $\alpha$ does not have any established equivalent or consistent corresponding term in Hebrew. And those Hebrew words

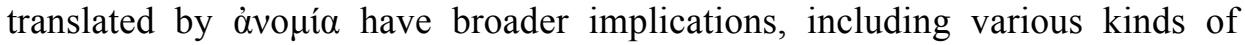
iniquity, evil, wickedness and disobedience.

In addition, some translations seem to be equivalent to each other. For

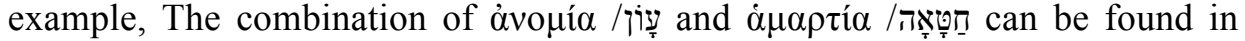
Neh 9:2; Ps 31:1, 5; 37:4-5; 37:19; 50:4, 5, 7, 11; 58:4; 84:3; 108:14; Job 10:6; $13: 23$; Isa $6: 7 ; 43: 25 ; 44: 22 ; 59: 12$; Jer $5: 25 ; 16: 18$. These contexts show that those words are close to each other in implication. In Exod 34:7, 9; Lev 16:21;

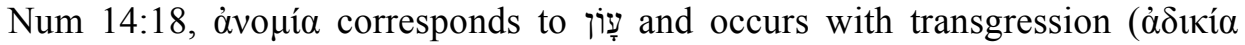

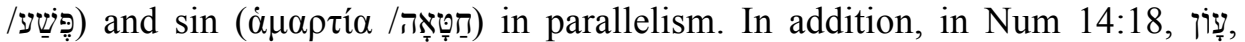
which is translated as $\dot{\alpha} v o \mu i \alpha$, also corresponds to $\dot{\alpha} \mu \alpha \rho \tau i \alpha$, which is often translated from is translated as $\alpha$ ó $\mu_{i} \alpha$ in Isa. 58:1; Lam 4:6; Ezek 18:21; 33:10.

Throughout the OT, wickedness and iniquity refers to disobedience to God and implies any failure in observance of God's Torah. However, clear reference to failure to observe Torah is not major among those instances of $\alpha v o \mu i ́ \alpha$ in the $\mathrm{LXX}^{2}$

2 On the clear reference to Torah or God's commandment, see Exod 34:7, 9 (oath of God in giving of the Ten Commandments); Lev 16:21(the context refers to the ritual for covenantal atonement); Lev 19:29; 20:14; 22:16; 26:43 (fornication and other misconduct against the law); Deut 31:29 (prophecy of Moses athat the Israelites will act corruptly and turn aside from the Law after his death); 2Sam 22:24 (related to the reference to God's statutes in v23); Ps 17:24 (violation of God's statutes in v23); Ps 73:20 (treachery against the covenant); Ps 118:3, 133,

William Loader, Boris Repschinski, Eric Wong (Eds.)

Matthew, Paul, and Others: Asian Perspectives on New Testament Themes

(C) 2019 innsbruck university press, ISBN 978-3-903187-66-5, DOI 10.15203/3187-66-5 
This observation indicates that lawlessness as disobedience to Torah is not a major meaning of $\dot{\alpha} v o \mu i ́ \alpha$ in the LXX and in its correspondent Hebrew words. ${ }^{3}$ However, it is clear from usage in the NT that this does not mean that òvouía had lost any implied reference to failure to observe Torah.

\section{Avouía in New Testament}

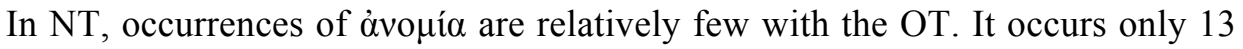
times, including four times in Matthew and four times in Pauline letters (Rom $4: 7 ; 6: 19 \times 2 ; 2$ Co $6: 14)$.

In Pauline usage, Rom 4:7 is the quotation from Psa 31:1 LXX. Although there is no clear reference to Torah observance in Psa 31:1, it seems that here Paul understands $\alpha \nu o \mu i ́ \alpha$ as the lack of it because he argues in this context about righteousness apart from works of the law. And Rom 6:19 talks about $\alpha v o \mu i^{\alpha} \alpha$ as iniquity in the context of contrasting righteousness and the works of the law. These instances show that Paul understands $\alpha v o \mu$ í $\alpha$ as discordance with the law, even though he argues that this problem should be solved not by the works of the law but by grace.

Contrary to Paul, Matthew argues that lawlessness is the problem. While this word appears only four times $(7: 23 ; 13: 41 ; 23: 28 ; 24: 12)$, every instance is found in a polemical context and reveals a trace of Matthew's highly redactional composition. This indicates that Matthew is greatly concerned about the issue of àvouía.

\section{A Clear and Present Crisis: The Existence of an Antinomian Sub-Group in the Matthean Community}

Among the scholarly attempts to find the meaning of the term $\alpha v o \mu$ í $\alpha$ in Matthew, Gerhard Barth (1963) argued that Matthew's polemic concerning

150 (opposition to God's instruction and the law); Ezek 11:18, 20 (ritual impurity and corruption against God's statutes); Ezek 16:2, 36, 43, 47, 51, 58 (idolatry); Ezek 43:8 (idolatry); Ezek 44:6-7 (impairment of the Temple and corruption of the covenant). In addition, one can include Ps 54:4, 10, 11 (enemy's violation of God's covenant, cf. v21) and Ps 102:3, 10, 12 (iniquities and transgressions as treachery against covenant and commandments, cf. v18).

3 Dodd $(1935$, p. 80$)$ points that this tendency of LXX to reduce various Hebrew ethical vocabulary into few words shows growing legalism in Hellenistic Judaism as the background of LXX.

William Loader, Boris Repschinski, Eric Wong (Eds.)

Matthew, Paul, and Others: Asian Perspectives on New Testament Themes

(C) 2019 innsbruck university press, ISBN 978-3-903187-66-5, DOI 10.15203/3187-66-5 
$\dot{\alpha} v o \mu$ í $\alpha$ has two fronts. Criticizing the Pharisees, Matthew asserts the correctness of his interpretation of the law. At the same time, he defends the validity of Jewish law in its entirety against those who insisted that Christ had abolished the law, accusing them of àvouía. Referring to Matthew 5:17ff., Barth argued that Matthew's opponents insisted that the law and the teachings of the prophets were no longer valid. He argued that the alteration in Matthew 11:13 from Q supports this supposition. He examined the possibility that those opposed to Matthew's view were Paulinists, then concluded that they could not be because the Matthean debate does not contrast good works with faith as does the epistle of James (especially Jam 2:14-26). He further argued that those antinomians must be Hellenistic Christians because it was unthinkable for any group in Judaism or Jewish Christianity to deny the validity of the law, although he concedes that no other details of this group can be determined. Barth further contended that we may not find anything more than that Matthew's ideological opponents insisted that the validity of the law ended with the coming of the Christ.

Ulrich Luz also admitted that nothing could be said precisely about this group except that "they simply did not live up to the strict standards of Matthew's interpretation of God's will -that they were, in other words, 'imperfect'" (Luz, 2007, p. 377). However, he also contended that "the intensive Matthean redaction is understandable only if the struggle with false prophets is an actual problem in his community" (Luz, 2007, p. 376). And "doers of lawlessness" in 13:41 refers to "all who do not hold fast to the biblical law that has its apex in the love commandment" (Luz, 2001, p. 269) and his church is involved in a dramatic and critical situation to confront them (Luz, 2005, p. 193-194).

\section{Expanding Laxity in Christianity}

James E. Davison (1985) disputed Barth's implicit assumption that Matthew uses $\dot{\alpha} v o \mu i \alpha$ with special reference to antinomian opponents. Through a semantic examination of the usage of dovouí $\alpha$ in LXX, Jewish literature, and Matthew, Davison concluded that $\dot{\alpha} v o \mu i ́ \alpha$ in Matthew does not support any antinomian interpretation of this term. In LXX, $\alpha v o \mu i ́ \alpha$ is employed as a

Luke 16:16 argues that the validity of the prophets and the law lasted until the time of John. Matthew alters the phrase to say that all the law and the prophets had been prophesied by the time of John and seems to uphold the validity of Torah.

William Loader, Boris Repschinski, Eric Wong (Eds.)

Matthew, Paul, and Others: Asian Perspectives on New Testament Themes

(C) 2019 innsbruck university press, ISBN 978-3-903187-66-5, DOI 10.15203/3187-66-5 
translation for twenty-four different Hebrew terms that connote various kinds of bad conduct. On the other hand, $\dot{\alpha} v o \mu i ́ \alpha$ is used interchangeably with a number of other terms which means evil actions which violate God's will. While d’vouía indeed refers to various evil deeds including violation of God's law, it does not mean exactly antinomianism. He contends that if we want to find a connection between $\alpha \dot{\alpha} o \mu i \alpha$ and antinomianism in Matthew, we must find evidence of such use that goes beyond the general usage of óvouía. For Matthew 7:21-23, Davison argued that the point of accusation concerns a certain laxness in their lifestyle that prevents believers from bearing any good fruits. He contended that there is no positive evidence of opponents who embrace antinomian doctrine (Davison, 1985, p. 629). In Matthew 13:41, Davison noted that the usage accords with its general meaning in LXX and Jewish literature, that is, a "very general, nonspecific sense for those who act contrary to God's will" (Davison, 1985, p.630). In his discussion of Matthew 24:10-12, he again concludes that $\dot{\alpha} v o \mu i ́ \alpha$ does not refer to any specific sins or false teachings. False prophets are indeed false teachers, but we are not able to discern the details of their teaching from Matthew, which does not describe them specifically. False prophets are seen as "one of a number of ways in which anomia is multiplied upon the earth" (Davison, 1985, p. 633). In examining Matthew 23:28, Davison leaves only brief comments concerning this issue, because it is apparent that the opponents in this context are Pharisees. They are "doers of àvouía" in contrast to righteousness, but should not be considered antinomians. As the conclusion of his whole argument, Davison contended that the target of óvouí $\alpha$ in Matthew is the problem of "laxity in the moral life of believers" (Davison, 1985, p. 634) and the Matthean usage of $\alpha v o \mu i ́ \alpha$ in accusations against Matthew's opponents has its root in his strong concern for God's law (nomos).

\section{A Phantom Menace: Avouía as a Future Threat}

David C. Sim (2010) considers ḋvouía in his argument about the polemical nature of Matthew's Gospel, focusing on the four distinct opponents of Matthew's polemics (the scribes and Pharisees, false Christians, the Roman Empire, and the Gentiles). He correctly suggested that the harsh polemic in Matthew reflects proximity to these opponents rather than distance from them, because the precise purpose of such polemic is to repel one's opponents. He suggested that the harsh polemic against the scribes and Pharisees reflects Matthew's competition with them for legitimacy of his own authority in the

William Loader, Boris Repschinski, Eric Wong (Eds.)

Matthew, Paul, and Others: Asian Perspectives on New Testament Themes

(C) 2019 innsbruck university press, ISBN 978-3-903187-66-5, DOI 10.15203/3187-66-5 
development of Judaism. In contrast to the physical proximity of the scribes and Pharisees, the other $\alpha \dot{\alpha} o \mu i \alpha$ (such as false Christians) had no direct contact with Matthew, Sim argued. He reasoned that the lack of detail about óvouía workers was due to their being a potential future threat but not a current problem. He argued that the $\dot{\alpha} v o \mu i ́ \alpha$ in Matthew 7:23 and 13:43 are law-free Christians still not in direct contact with the Matthean community. Thus, the polemic of Matthew was created at the ideological level and "not occasioned by the physical proximity of these false Christians" (Sim, 2010, p. 503). Instead, he argued, their proximity is purely ideological. Despite their ideological proximity, there was a definite difference between Matthew and them in their observance of the Torah. Matthew accuses law liberal Christians as being $\dot{\alpha} v \mu_{1} \alpha$ along with the scribes and the Pharisees because their Torah practice fails to follow the definitive interpretation of Jesus.

\section{The Other Clear and Present Crisis: The Double Criteria of Torah Observance}

Anders Runesson (2016) refused to identify $\dot{\alpha} v o \mu$ í $\alpha$ with "antinomian Christians." Instead he suggested that the problem of àvouía relates to judgment on Jews who "have a covenant relationship with the God of Israel" (Runesson, 2016 , p. 27). He investigated the theme of divine wrath and judgment on the narrative level of the Matthean story and argued that the divine judgment in Matthew "should be analyzed separately with regard to Jews and non-Jews" (Runesson, 2016, p. 27). Because the law is a covenant obligation for Jews,

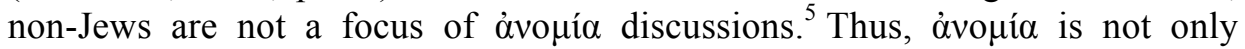
"failure to act in a manner that conforms to the stipulation of the Torah" (Blanton, 2013) but also a failure to follow Jesus through Torah practice following Jesus' interpretation motivated by love for God and neighbor (Runesson, 2016, p. 77). Runesson argued that the distinct harshness of the polemic is not motivated by the immediate threat of Matthew's opponents, but is rooted in severe threats of judgement in the prophetic literature and shaped by

Runesson (2016) also discussed Matthew's notion of “the possible salvation of the outsider, as outsider, under certain circumstances (25:31-46)" (p. 442). He treated the issue of outsiders in detail in pp. 343-392 and pp. 393428.

William Loader, Boris Repschinski, Eric Wong (Eds.)

Matthew, Paul, and Others: Asian Perspectives on New Testament Themes

(C) 2019 innsbruck university press, ISBN 978-3-903187-66-5, DOI 10.15203/3187-66-5 
eschatological expectation of imminent divine judgment (Runesson, 2016, p. 27 and p. 442).

\section{Contradiction in Matthean Polemic}

Hence, we have considered four important directions for the interpretation of the $\alpha v o \mu i \alpha$ in Matthew. Because each direction outlined above has its own legitimate basis, an apparent contradiction emerges.

The lack of detailed descriptions of àvoría seems to attest to the absence of physical proximity or even the existence of $\dot{\alpha} v o \mu$ í $\alpha$-practicing opponents. However, Matthew's intensive redaction of those texts concerning $\alpha v o \mu$ í $\alpha$ focuses on harsh polemic against $\dot{\alpha} v o \mu$ í $\alpha$. The harshness of Matthean polemic suggests that Matthew was involved in an immediate struggle with them.

Runesson attempted to account for both the urgent mood of the polemic and the failure to identify the opponents on the basis of imminent expectation of divine judgment. His analysis is convincing, especially when we reconsider of the nature of the Matthean Gospel as "a specific eschatologically-oriented variant of Second-Temple Judaism" (Runesson, 2016, p. 442). However, we also need to examine how Matthew evaluated other Christian movements and teachings. In particular, Matthew's articulation of Markan texts seems to hint at criticism of Mark's Torah-free text. ${ }^{6}$

To resolve the apparent conflict found in the Matthean text and to supplement Runesson's argument, this study hereafter attempts an exegetical analysis of the usage of $\dot{\alpha} v o \mu i ́ \alpha$ in Matthew.

\section{Matt 7:21-23: practitioners of $\alpha$ vouía calling on the Lord in the end days}

This passage is a part of the conclusion of the sermon on the mount (Matthew 57), which has a parallel in Luke 13:25-27. In the Lukan version, both the appeal and the denial are set in a parable of Jesus and the claim of people for acceptance is based on the intimate relationship between them and the housekeeper. In the Matthean version, their cause is based on the fact that they

6 For anti-Paulinism in Matthew, see Sim (2008) and Sim (2014); Wong (2012) also finds anti-Paulinism in Matthew; Park (2015) suggests that Matthew opposes the dominant Christian theology of his time, yet acknowledges it as "Pauline." For parallels between Paul and Mark, see Marcus (2000) and Telford (1999). Svartvik (2008) argues that Matthew intended to remake, to rejudaize Mark, the Pauline Gospel.

William Loader, Boris Repschinski, Eric Wong (Eds.)

Matthew, Paul, and Others: Asian Perspectives on New Testament Themes

(C) 2019 innsbruck university press, ISBN 978-3-903187-66-5, DOI 10.15203/3187-66-5 


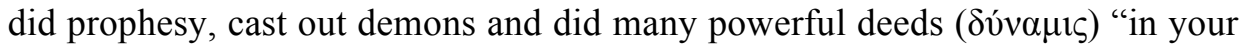
name" ( $\tau \tilde{\omega} \sigma \tilde{\varphi}$ ỏvó $\mu \alpha \tau)$ ). They are not condemned for performing these activities because they represent the fulfillment of apostolic commission (cf. Matthew 10:8) (Hagner, 1993, p. 188). Nor are they criticized for performing these activities in the name of Jesus without his permission (cf. Luke 9:4-50). The context rather suggests an interpretation in which their activities are condemned for diverging from "the will of my father in heaven" ( $\tau$ ò $\theta \dot{\varepsilon} \lambda \eta \mu \alpha \tau o \tilde{v} \pi \alpha \tau \rho o ́ \varsigma \mu o v$

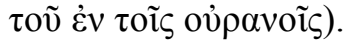

Because Matthew 7:21 refers back to 5:20 ("unless your righteousness exceeds that of the scribes and Pharisees, you will never enter the kingdom of heaven."), $\dot{\alpha} v o \mu$ í $\alpha$ here could be understood to mean lawlessness through the failure to fulfill the demands of God's law (thus, a lack of righteousness).

$7: 21 \mathrm{ff}$. also relates to $7: 24$, which states "everyone then who hears these words of mine and acts on them" ( $\pi \tilde{\alpha} \varsigma$ oṽv ö

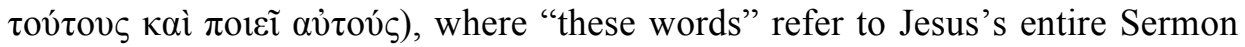
on the Mount. Thus, following "the will of my Father in heaven" (v21) entails observance of every single teaching given by Jesus in that sermon. No matter how remarkable the activities of the condemned, they are unacceptable if not in accordance with the teachings of Jesus.

Thus, the problem is how one can be in accordance with the teaching of Jesus and the will of God? The criticism against the scribes and the Pharisees in Matthew 23 reveals that this is a matter of inner motive.

\section{Matt 23:27-28: Scribes and Pharisees as guilty of óvouía}

This statement is a part of the strong condemnation of the scribes and the Pharisees in Matthew 23:1-36. This pericope consists of seven woes; the present statement is the sixth. This accusation has its origin in Mark 12:36, and the fact that some phrases have parallels in Luke 11:37-54 and 20:45-47 shows that these verses have their source in Q. Nevertheless, it is Matthew who redacted those materials into a strong criticism of the scribes and the Pharisees within the well-crafted structure of seven-fold woes. Out of all of these, the present accusation is unique to Matthew. Although inheriting the clear inside/outside contrast from Q, its abundance of characteristically Matthean terms confirms that the text has undergone intense redaction by Matthew. The scribes and the Pharisees are the clear targets of $\alpha v o \mu i ́ \alpha$ here. They are listed as bad examples to

William Loader, Boris Repschinski, Eric Wong (Eds.)

Matthew, Paul, and Others: Asian Perspectives on New Testament Themes

(C) 2019 innsbruck university press, ISBN 978-3-903187-66-5, DOI 10.15203/3187-66-5 
be overcome in Matthew 5:20. Even though they should be experts in God's law, like the subjects of other $\alpha v o \mu$ í $\alpha$ passages, they fail to achieve righteousness by practicing it perfectly. However, the exact content of $\alpha v o \mu$ í $\alpha$ here is still unclear. The seven woes are a list of various activities, but the problem is not the activities, for the scribes and the Pharisees indeed observe the commandments in God's law. Nevertheless, Matthew accuses them of not practicing the commandments that they teach (Matthew 23:3). Certainly, they do practice various activities concerning the God's law, but from Matthew's perspective, they do not really practice it. Thus, their activities themselves do not comprise $\alpha v o \mu i ́ \alpha$, but their motives run counter to God's will, making them practitioners of $\dot{\alpha} v o \mu i ́ \alpha$. They only practice to be seen by others (23:5), but the problem here is not outward ( $(\xi \xi \omega \theta \varepsilon v)$ but inward ( $\left.\varepsilon^{\prime} \sigma \omega \theta \varepsilon v\right)$. Both their practice and lack of practice reveal their inner drive toward $\alpha v o \mu i ́ \alpha$ (23:8). Thus, Matthew criticizes their failure of proper motivation. Perfect practice of God's law demands both outward practice and inner motive. Matthew points out that this inner motive shall be called love (Runesson, 2016, p. 76-78).

Matt 24:9-14: òvouía in end days

This passage is a part of the series of apocalyptic prophecies in chapter 24 . Together with its parallel in Luke 21:7-19, it is derived from Mark 13:3-13. Matthew has already used the source in Matt 10:17-22, and at this time, he makes more crafted and greater redaction on it. ${ }^{7}$

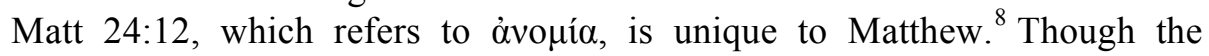
details of $\dot{\alpha} v o \mu i \alpha$ are neither illustrated nor presented, it is clear here that increased $\dot{\alpha} v o \mu i \alpha$ results in the love of many growing cold. As this love is the essence of the law for Matthew, $\alpha v o \mu$ í $\alpha$ behaviors cool the love of many. As previously noted, $\dot{\alpha} v o \mu$ í $\alpha$ refers to imperfection in observation of the law. It weakens the love that can be realized through perfect observation of the law.

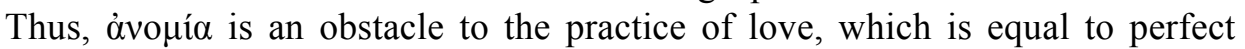
observance of the law. Thus, $\dot{\alpha} v o \mu i ́ \alpha$ is the opposite of the practice of love.

\footnotetext{
$7 \quad$ For example, repetition of the combination of $\alpha \lambda \lambda \eta \dot{\lambda} \omega \nu$ and verbs, repetition of $\pi \alpha \rho \alpha \delta i \delta \omega \mu \mathrm{t}$ and $\mu 1 \sigma \varepsilon \dot{\omega}$ in v9 and

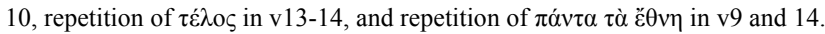

8 Luz (2005, p.183) asserts on the ground of the context that v10-12 come from Matthew and are not based on a source. In any case, $\alpha$ vo $\mu$ í $\alpha$ is introduced here by Matthean intentional redaction.
}

William Loader, Boris Repschinski, Eric Wong (Eds.)

Matthew, Paul, and Others: Asian Perspectives on New Testament Themes

(C) 2019 innsbruck university press, ISBN 978-3-903187-66-5, DOI 10.15203/3187-66-5 
In 24:14, Matthew omits "first" ( $\pi \rho \tilde{\omega} \tau \circ \zeta)$ from Mark 13:10 and moves this sentence to the end of the passage to serve as the conclusion of the present pericope. Here we find Matthew's intention to make a connection with the mission to all nations at the end of the world. The mission to all nations has already commenced around him and will bring about the end of this world (Luz, 2005, pp. 194-195). For Matthew, a sense of urgency surrounds the present situation, since the mission to all nations has already started. Thus, in 24:14, Matthew emphasizes that this apocalyptic situation, the progress of the mission to all nations, relates to $\dot{\alpha} v o \mu$ í $\alpha$, which cools the love of many, namely, weakens inner motive to follow Jesus by fully observing the law.

Matt 13:41-42: The practitioners of $\dot{\alpha} v o \mu$ í $\alpha$ as the tares in the field

Matthew weaves the parable of the tares (13:24-30) and its interpretation (13:36-43) into two Markan parables (the parable of the sower [Matt 13:1-23; from Mark 4:1-20; Luke 8:4-15 par] and the parable of the mustard seed [Matt 13:31-33; from Mark 4:30-32; Luke 13:18-21 par]). It is probable that Matthew based the parable and its interpretation on tradition (Luz, 2001, p. 253 and pp. 267-268). Matt 13:36-43 also forms a bridge from the former sequence of parables to two additional parables unique to Matthew (13:44-50; 51-52). Thus, the whole framework of chapter 13 is created by Matthew.

The parable of the tares and its interpretation show that in the field, which means the whole world, there so far exist wheat and tares, which means "the children of the kingdom" and "the children of the evil one." However, they will be separated during the harvest, meaning at the end of the world. Matthew repeats the phrase of $\mathrm{v} 42$ ([They] "will cast them into the furnace of fire. There will be wailing and gnashing of teeth.") in v50 again; this parallels the rejection of bad trees (7:19). Matthew often uses the phrase "wailing and gnashing of teeth" combined with the motif of casting out to indicate judgment at the end of the world (Matt 13:42, 50; 22:13; 24:51; 25:30).

In the present pericope, the practitioners of $\alpha v o \mu$ í $\alpha$ are viewed as parallel to "the tares," "the children of the evil one" (v38) and "all those who stumble" (v41), and opposed to "the children of the kingdom" (v38) and "the righteous" (pl., v43). Though here again the exact nature of ávo $\mu$ í $\alpha$ is neither illustrated nor

William Loader, Boris Repschinski, Eric Wong (Eds.)

Matthew, Paul, and Others: Asian Perspectives on New Testament Themes

(C) 2019 innsbruck university press, ISBN 978-3-903187-66-5, DOI 10.15203/3187-66-5 
presented $^{9}$, Matthew uses apocalyptic expressions to emphasize harsh judgment against them at the end of the world.

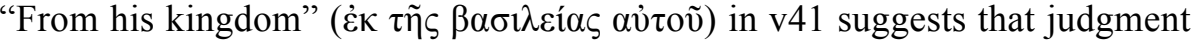
may be passed on the church as a mixed community that embraces $\alpha v o \mu i \alpha$ : the tares and the children of evil, together with the righteous and the children of the kingdom (Luz, 2005, p. 193). However, this interpretation is inconsistent with Matthew's assertion that "the field is the world" (Matt 13:38). This apparent inconsistency can be resolved by considering the "mixed community" to be the whole world (spread with Christian mission) rather than a certain church community. ${ }^{10}$ This interpretation suggests that Matthew critically views the Christian mission for all nations as serving to gather not only the righteous but also the practitioners of óvouía. ${ }^{11}$ Matthew expresses concern about this situation as an apocalyptic crisis as the end time comes near (Matt 24:11-14).

Thus, through interpretation of the relevant pericopes, we have found the following:

1) àvouí $\alpha$ means the failure to observe God's law perfectly according to the teachings of Jesus.

2) $\alpha$ vo $\mu^{\prime} \alpha$ connotes not only the outward practice of the law, but also an insufficiency of internal motivation to observe it perfectly. Thus, $\alpha \dot{\alpha} o \mu i^{\alpha} \alpha$ leads to an apocalyptic situation in which the love of many grows cold.

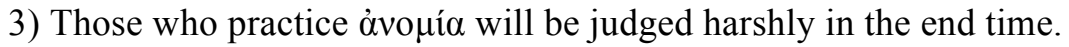

4) Judgment will be passed not only on the church community but the whole world as a mixed community as a result of the mission to all nations.

5) Matthew is critical of the growing mission to all nations which brings about not only righteousness but also $\alpha{ }^{2} o \mu i^{\alpha} \alpha$.

Thus, Matthew criticizes the failure of the mission to all nations to cultivate perfect observance of God's law, not only in outer practice but inner motivation. This problem exists not only within the Matthean movement (or community) but in every place touched by the mission to all nations. As Matthew aims his

Luz (2001, p. 269) suggested, based on the contexts of Matthew 7 and 24, that they lack loving observance of the law.

10 Luz admits the possibility of such a situation, though he contends that the future is still unknown for Matthew himself. "It is a long way from Matthew's small minority community to the corpus permixtum of the reformers. One may argue that the reformers' theological solution is consistent. When the national church, that in its place can scarcely be distinguished from the world, has taken the place of the minority church, then it must be -even in Matthew's sense- a corpus permixtum" (Luz, 2001, p. 272).

11 Wong (2012, pp. 116-119) suggests that the sower of the tares implies a reference to the apostle Paul.

William Loader, Boris Repschinski, Eric Wong (Eds.)

Matthew, Paul, and Others: Asian Perspectives on New Testament Themes

(C) 2019 innsbruck university press, ISBN 978-3-903187-66-5, DOI 10.15203/3187-66-5 
accusation not only at his own movement (community) but the whole world, his criticism bears a tone of urgency and harshness, but does not focus on the details of instances or practitioners of $\dot{\alpha} v o \mu$ í $\alpha$.

Though the mission to all nations is an inevitable reality, Matthew attempts to shift its direction toward Torah-observance, insisting that without teaching followers to "obey everything that I have commanded you" (28:20), the mission would be òvouía.

\section{Conclusion}

The fact that Matthew employs $\dot{\alpha} v o \mu i$ in in the context of apocalyptic judgement reflects his urgent belief the end of the world was coming.

$\dot{\alpha} v o \mu$ í $\alpha$ concerns the observance of the law, not only through outer practice but also through inner motivation. Following Jesus with perfect observance of the law through love is the only way to meet the conditions of righteousness. The Pharisees and scribes lack sufficient inner motive to revere Jesus, while non-Torah-observant Christians fail through lack of practice.

Matthew's Gospel is set in the context of the emergence of the Pharisees and the spread of the mission to all nations without devout observance of Torah. Matthew intends to steer the direction of the mission toward the observation of the Torah in accordance with Jesus' instructions.

\section{$7 \quad$ Bibliography}

Barth, G. (1963). Matthew's Understanding of the Law. In G. Bornkamm, G. Barth and H. J. Held (Eds.), P. Scott (Trans.), Tradition and Interpretation in Matthew (pp. 58-164). London: SCM Press.

Blanton, T. R., IV. (2013). Saved by Obedience: Matthew 1:21 in Light of Jesus' Teaching on the Torah. JBL, 132 (2), 393-413.

Davison, J. E. (1985). ANOMIA and the Question of an Antinomian Polemic in Matthew. JBL, 104(4), 617-635. doi: 10.2307/3260675

Dodd, C. H. (1935). The Bible and the Greeks. London: Hodder and Stoughton. Hagner, D. A. (1993). Matthew 1-13. Dallas, TX: Word.

Luz, U. (2001). Matthew 8-20: A Commentary. (J. E. Crouch, Trans.). Minneapolis: Fortress.

Luz, U. (2005). Matthew 21-28: A Commentary. (J. E. Crouch, Trans.). Minneapolis: Fortress.

William Loader, Boris Repschinski, Eric Wong (Eds.)

Matthew, Paul, and Others: Asian Perspectives on New Testament Themes

(C) 2019 innsbruck university press, ISBN 978-3-903187-66-5, DOI 10.15203/3187-66-5 
Luz, U. (2007). Matthew 1-7: A Commentary (Revised). (J. E. Crouch, Trans.). Minneapolis: Fortress.

Marcus, J. (2000). Mark-Interpreter of Paul. NTS, 46(4), 473-487.

Park, E. E. C. (2015). Covenantal Nomism and the Gospel of Matthew. CBQ, 77(4), $668-685$.

Runesson, A. (2016). Divine Wrath and Salvation in Matthew: The Narrative World of the First Gospel. Minneapolis: Fortress Press

Sim, D. C. (2008). Matthew, Paul and the origin and nature of the gentile mission: The great commission in Matthew 28:16-20 as an anti-Pauline tradition. HTS 64, 377-392.

Sim, D. C. (2010). Polemical Strategies in the Gospel of Matthew. In O. Wischmeyer and L. Scornaienchi (Eds.), Polemik in der frühchristlichen Literatur (BZNW 170), (pp. 491-515). Berlin: De Gruyter.

Sim, D. C. (2014). The Reception of Paul and Mark in the Gospel of Matthew. In O. Wischmeyer, D. C. Sim, \& I. J. Elmer (Eds.). Paul and Mark: Comparative Essays. Part I: Two Authors at the Beginnings of Christianity, (pp. 589-615). Berlin: De Gruyter.

Svartvik, J. (2008). Matthew and Mark. In D. C. Sim, B. Repschinski (Eds.). Matthew and His Christian Contemporaries, (pp. 27-49). London: T\&T Clark.

Telford, W. (1999). The Theology of the Gospel of Mark. Cambridge: CUP.

Wong, E. K. C. (2012). Evangelien im Dialog mit Paulus (NTOA 89). Göttingen: Vandenhoeck \& Ruprecht. 
